\title{
Translating the village
}

\section{Translation as part of the everyday lives of asylum seekers in Italy}

\author{
Andrea Ciribuco \\ National University of Ireland Galway
}

\begin{abstract}
This article explores translation in the lives of asylum seekers from various African countries living in state-provided accommodation in the region of Umbria, Italy. While (semi) professional translators and interpreters play a crucial part in interactions between institutions and asylum seekers, translation invests the totality of the asylum experience. Translation is a vital skill for asylum seekers, and their interactions with the landscape of Italian villages involve the transfer of meaning across different languages and semiotic systems (such as body language, social norms, and cultural practices). Building on recent semiotic and spatial approaches to translation, this article examines the experience of translation that emerged from conversations with asylum seekers, providing an overview of a complex ecosystem of translation and shedding light on the everyday reality of refugee integration.
\end{abstract}

Keywords: translation, asylum, integration, Italy, intersemiotic translation

\section{Introduction}

Translation and interpreting play an important part in the asylum experience. Asylum seekers interact with professional or semi-professional interpreters in courts, police stations, hospitals (Inghilleri 2005; Jiménez-Ivars and León-Pinilla 2018; Killman 2020). This research investigates the role of translation in the lives of asylum seekers in Italy; not, however, from the perspective of their interaction with (semi) professional translators, but rather by looking at their own translation activities and how they connect the asylum seekers with the space that they precariously inhabit.

This study investigates translation as the human ability to understand and transform meaning: an everyday activity performed not only by professionals, which can, among other things, facilitate connections between migrants and 
locals. Based on the latest evolution of Translation Studies in the spatial and semiotic sense, this study argues for the research focus on translation to expand and include not only textual activities but also the lived experiences of translating individuals. This involves exploring a relationship between the individual and various types of meaning in the landscape (linguistic and non-linguistic); which offers challenges and occasions for (mis) communication in an asylum seeker's quest for survival and belonging.

Between December 2018 and September 2019, I interviewed asylum seekers from various West African countries living in villages and small towns in the Italian region of Umbria. In the age of globalisation, it is easy to think of diversity as a feature of urban space - often in the form of 'superdiversity' (Vertovec 2007). Metropolises are multilingual almost by definition, and most research on language contact has focused on urban areas, which "is not to suggest that towns, villages or hamlets may not be contexts of diversity, but rather that diversity is more commonly intensified in larger spaces." (Pennycook and Otsuji 2015,29) This research covers ground that is not usually the object of translation or multilingualism research, investigating how translation (or lack thereof) influences the lives of newcomers in small communities.

I will analyse the asylum seekers' narratives of integration into communities to investigate the role of translation in their everyday lives, in the negotiation of meaning, and in the performance of activities that may improve their sense of belonging. The analysis includes not only examples of interlingual translation, but also of translation involving other types of meaning (body language, social and cultural norms, cultural practices). Through this process, I intend to investigate whether it is possible, by enlarging the focus of translation research, to capture the different negotiations that enable an individual to adapt to a new landscape - and paint a picture of integration processes that has the translating migrant at its centre.

After a brief overview of recent literature, I will illustrate the methodology for this study in relation to the context of asylum in Italy. Then I will briefly discuss the linguistic background of research participants and analyse the occasions for interlingual translation that they encounter in their everyday life, even when there is no translator present. The last two sections of the article will examine the translational aspects of interactions between asylum seekers and locals that are not generally branded as translation: street encounters and communal activities (with a focus on sports). 


\section{Towards a semiotic understanding of Translation}

Translation is increasingly researched as a feature in the development of societies and as something that is spatially determined. The spatial understanding of translation is indebted to concepts developed during Translation Studies' 'cultural turn' in the 1980s and 1990s, such as Mary Louise Pratt's idea of "contact zones." (1991) The 'social turn' that followed expanded on some of those concepts with the help of sociological tools to investigate how translation performs or challenges relations of power (Wolf 2011). This also enabled the study of cities as spaces of translation (Simon 2012). Spatial and ecological understandings of translation shift the focus from an ethnos-based view to a place-based one, "an ecological notion of translating in situ" where "place not race becomes the marker of collective significance and collective emancipation." (Cronin 2017,1.3) Translation is at the centre of community-building, regulating the transfer of meaning between and within locales - which includes power relations between dominant and minority cultures, or between autochthonous and newly arrived residents.

Moira Inghilleri notes how migrants' opportunities to gain "agency over their reception" depends on their ability to "map themselves onto different terrains, carving out their place in pre-existing spaces, possessing and altering them in meaningful ways." $(2017,108)$ Pre-inhabited spaces have features that need to be decoded and understood: meaningfully "possessing and altering" these spaces means first coming to terms with the landscape as realised through the signs, the objects, the distances and practices that are considered 'normal'. Subsequently, it means making one's presence known and visible in a way that is accepted and recognised by the locals, by making connections between one's repertoire and the signs of the new landscape.

If migrants and refugees adapt by translating continuously, that process necessarily resembles less and less the work of a professional translator or interpreter. Much of the meaning that migrants interpret and create in a landscape is not (or not only) expressed in linguistic terms - and even interlingual translation is indeed predicated on available material resources and spatial dispositions. Translation Studies is no stranger to translation across different modes of communication, although this mostly has involved the study of specific multimodal texts such as comic books or subtitled films. Understanding translation in space certainly means looking at different modes of communication, and at how translation evolves in relation to the availability of technologies and media (Littau 2016). However, an encompassing study of how people "map" themselves onto a different landscape (to use Inghilleri's terms) requires a focus on a range of semiotic systems such as body language, foodways, art - to name but a few. 
While Roman Jakobson's tripartite understanding of translation (1959) already included the notion of intersemiotic translation, the classic understanding of translation is biased towards interlingual translation, which Jakobson called "translation proper." Investigating translation in society, however, requires us to look at interlingual translation as part of a wider management of differences in meaning, concepts, and ideologies. Kobus Marais has identified a series of challenges that translation studies as a discipline faces concerning its key object of study, proposing that, rather than attempting to define what a translation is (and what it is not), the discipline may instead look at translation-related aspects of reality:

There is no 'pure' translation phenomenon: there is reality, and the way in which translation scholars have decided which aspects of it they consider. The question should not be "is this translation?" but "what is translational about this?"

(Marais 2014, 76)

Building on this, Marais recently proposed a reconceptualisation of translation based on Peircean semiotics and its notion that the meaning of a sign is its translation into another sign. He understands translation as "creating relationships between (inter) signs and between signs and things and between signs and ideas, etc." (Marais 2019,138) 'Translation' here would be the name given to the continuously emergent relationship between signs belonging to different meaningmaking systems, through which new meaning enters the world. This includes language being connected to a different language; but also taste and language, poetry and music, political ideologies and gestures, etc. Reconceptualising translation in the semiotic sense means doing away with the notion of the text to be translated and concentrating on how all meaning is reformulated into countless systems as humans interact with the landscape and each other.

Marais intends to eliminate Jakobson's tripartite distinction of translation, arguing that all translation is ultimately semiosis. This distinction may eventually be surpassed by the evolution of the discipline, but it still dictates many people's attitudes towards translation as they tend to use the term 'translation' only in relation to interlingual operations. Therefore, the distinction is still useful to my analysis of the lived experience of translation, as I first concentrate on interlingual operations that are explicitly named as translations by participants; and then on translations that, although they may not be acknowledged as such, are equally relevant to their experience of Italy. The goal is to have as complete as possible an overview of the role that translation plays in the life of the asylum seeker and of the many negotiations that create an ecosystem of translation - knowing that only some of them will be named explicitly as such. 


\section{Context and methodology}

An asylum seeker is someone who has left their country in search of safety from conflict or persecution and who has applied for asylum in another country - in the case of this study, Italy. A court will examine their claim and, if found to have a valid reason to fear for their lives in their home country, they will be granted the status of refugee (or another type of international protection) that will enable them to stay. Between 2013 and July 2018, approximately 685,000 asylum seekers reached Italy by crossing the Mediterranean. In 2017, agreements between Italy and Libya (a key transit country) generated a significant reduction in sea crossings: between July and December 2017, arrivals went down by $78 \%$ with respect to the previous year (Villa, Emmi, and Corradi 2018,10), and have not reached pre-2017 levels since.

During the months, and often years, leading to the asylum hearing, asylum seekers are hosted by the Italian refugee hospitality programmes in different types of accommodation (including small apartments as well as repurposed hotels). ${ }^{1}$ Several hospitality projects are in small towns and villages: in 2018 , roughly $70 \%$ of asylum seekers in the SPRAR/SIPROIMI programme were living in a town with fewer than 100,000 inhabitants, including $23 \%$ in towns with fewer than 5,000 inhabitants (Ministero dell'Interno 2018,15). This is where asylum seekers spend most of their time, in a precarious state, waiting for the bureaucratic process to unfold.

Italian classes were mandatory for asylum seekers and refugees until October 2018 when a new government issued a decree that, among other things, limited the criteria for international protection and significantly reduced funding for refugee integration. This effectively reduced integration services, including limiting Italian language classes to those who had already been granted refugee status. These provisions were coming into effect when I started interviewing asylum seekers in December 2018, which means that they had spent most of their time in Italy in a context where integration services were available to them.

Between October 2017 and September 2019, through a partnership between NUI Galway and the non-governmental organisation (NGO) Tamat, I took part in the latter's activities in Perugia, in the region of Umbria. I acted as a language

1. As of 2018, the Italian asylum seeker hospitality programme was made of two separate strands: CAS-Centro Accoglienza Straordinaria and SPRAR - Sistema di protezione per richiedenti asilo e rifugiati; the former being an "emergency" service, while the latter focused explicitly on social inclusion and support services. SPRAR was renamed SIPROIMI - Sistema di protezione per titolari di protezione internazionale e per $i$ minori stranieri non accompagnati in 2018. 
teacher in their social inclusion projects for refugees while researching language integration. The main goal of the research project is to study how refugees adapt and translate themselves to create links with the host society - investigating the different roles that home languages and the new language play in this trajectory. I worked with adult asylum seekers and refugees from West African countries hosted by hospitality programmes: this population was chosen for its numerical significance ${ }^{2}$ and for the presence of English or French in their repertoires (granting a degree of linguistic uniformity in their trajectories). While most of the project took place in the regional capital of Perugia, the present study concentrates on translation and integration in nearby villages to investigate how asylum seekers interact with small, tight-knit communities.

Recruitment involved participants (Table 1) with a specific profile: they came from West African countries, had entered Italy as asylum seekers through the Mediterranean route, and were hosted in refugee hospitality programmes in small towns in the Umbria region. The participants were recruited through a 'snowballing' technique among individuals who had either taken part in social inclusion events organised by Tamat, or who were assisted by stakeholders in Tamat's network. Contact was made through the staff of the reception centres. The group included 19 men and 3 women, roughly reflecting the gender distribution of the asylum seeker population in Italy (between 2014 and 2016, women were never more than $13.9 \%$ of sea arrivals). ${ }^{3}$ Their levels of Italian varied from beginner to intermediate/advanced, but they had all attended Italian classes as part of hospitality programmes.

The interviews took place in six towns in the Umbria region (with one village in Tuscany, on the Umbrian border) where the participants lived in reception centres. The towns' populations ranged from 2,689 to 11,177; some interviews took place in the offices of two NGOs in a bigger town, Terni (pop. 110,940), but most participants recruited there were hosted in smaller villages in the area and only visited the NGO offices to attend Italian classes or receive legal help.

The corpus consists of 19 semi-structured interviews (two interviews in [Village II] involved more than one participant at a time), audio-recorded and then transcribed. The median interview length was 51 minutes, the whole corpus amounting to 967 minutes. The interviews took place according to protocols

2. Out of the five most common nationalities for sea arrivals in 2016, four (Nigeria, Guinea, Ivory Coast, Gambia) are in West Africa. Source: Elaboration of UNHCR/Ministero dell'Interno data by ISMU, available at https://www.ismu.org/ricerca/aggiornamenti-crisiimmigrazione-in-europa/ (accessed 31/03/2020)

3. Elaboration of UNHCR data by ISMU, available at https://www.ismu.org/ricerca /aggiornamenti-crisi-immigrazione-in-europa/ (accessed 31/03/2020) 
Table 1.

\begin{tabular}{|c|c|c|c|c|}
\hline Participant & $\begin{array}{l}\mathrm{M} / \\
\mathrm{F}\end{array}$ & $\begin{array}{l}\text { Place of } \\
\text { interview }\end{array}$ & $\begin{array}{l}\text { Country of } \\
\text { origin }\end{array}$ & $\begin{array}{l}\text { Linguistic repertoire before arriving in } \\
\text { Italy (as declared) }\end{array}$ \\
\hline K.A. & M & Village I & Guinea & Malinke, French \\
\hline D.A. & M & Village I & Guinea & Malinke, Konianke, Susu \\
\hline S.A. & M & Village I & Nigeria & English, Igbo, Benin \\
\hline B.S. & M & Village II & Senegal & Mandé, French, Jula, Wolof, English \\
\hline A.L. & M & Village II & Senegal & Wolof, French \\
\hline L.R. & $\mathrm{M}$ & Village II & Senegal & Mandinka, Wolof \\
\hline S.D. & $\mathrm{M}$ & Village II & Senegal & Peul, French, Wolof \\
\hline J.P. & $\mathrm{M}$ & Village II & Senegal & French, Jula, Wolof, Mandinka, English \\
\hline T.L. & M & Village II & Liberia & $\begin{array}{l}\text { French, Arabic, English, Bambara, Susu, } \\
\text { Peul, Toma, Guerze, Konianke }\end{array}$ \\
\hline C.E. & $\mathrm{M}$ & Village III & Senegal & $\begin{array}{l}\text { French, Wolof, Mandinka, English, } \\
\text { Portuguese }\end{array}$ \\
\hline O.U. & $\mathrm{M}$ & Village IV & Sierra Leone & English, Krio, Temne \\
\hline S.F. & $\mathrm{M}$ & Village IV & Gambia & Mandinka, Wolof, English \\
\hline A.A. & M & Village IV & Togo & French, Kotokoli, Kabiyé \\
\hline F.V. & $\mathrm{F}$ & Terni & Nigeria & Igbo, English \\
\hline D.L. & M & Terni & Sierra Leone & English, Krio, Temne \\
\hline P.I. & $\mathrm{M}$ & Terni & Senegal & French, Wolof, Mandinka, English \\
\hline A.B. & $\mathrm{M}$ & Terni & Mali & Bambara, Mandingo, Arabic \\
\hline D.R. & $\mathrm{M}$ & Terni & Gambia & English, Wolof, Mandinka \\
\hline D.O. & $\mathrm{M}$ & Terni & Togo & French, Kotokoli, Ewe \\
\hline B.L. & $\mathrm{F}$ & Village V & Nigeria & Urhobo, English, Pidgin English, Benin \\
\hline K.V. & M & Village V & Nigeria & English, Benin, Yoruba \\
\hline J.Y. & $\mathrm{F}$ & Village $\mathrm{V}$ & Nigeria & English, Edo \\
\hline
\end{tabular}

agreed with the Research Ethics Committee at NUI Galway; participants are identified with acronyms and the status of their asylum application is not disclosed. ${ }^{4}$ Each interviewee was free to switch between Italian and English/French during the interview, which took place without an interpreter. This choice was dictated by the intention to see each participant as a translator of their own expe-

4. For this reason, I will refer to all participants as "asylum seekers" even though some of them had been granted refugee status at the time of the interview. 
rience, relying on different languages to convey different parts of the experience as they preferred. The semi-structured interviews started by asking the participants to briefly describe the linguistic situation in their home country, their own linguistic repertoire, and their educational background. Then, they would discuss their Italian classes, and other activities (such as traineeships and cultural activities) that they felt had improved their connection with the local community.

Translation studies have often focused on narratives as tales that not only represent, but also contribute to creating worldviews - and on how translators intervene in competing and evolving narratives. That includes the tension between asylum seekers' "very little room for negotiating a compromise between their ontological narrative and the institutional and public narratives of the host country" and their interpreters' preoccupations with objectivity (Baker 2019,31). While that approach is rooted in a social and communication theory of narratives, the present study is inspired by sociolinguists' use of language biographies (Nekvapil 2003; Busch 2017; Stevenson 2017). This is closely related to the idea that a linguistic repertoire is a product of one's biography - what Brigitta Busch calls an individual's "Spracherleben, the lived experience of language" $(2017,341)$ responding to personal motivation as well as socio-cultural constraints. Therefore, (auto) biographical narratives centred on the role of language in one's life can reveal wider connections to general language situations, policies and ideologies.

I have analysed the participants' 'lived experience of translation' by looking at substantive facts in their narratives: key moments where translation (or the lack thereof) impacted their experience in the community, as well as their comments about them. This includes instances that were explicitly acknowledged by participants as translation, such as using Google Translate; but also significant points in their journeys towards integration, where the participants do not explicitly discuss translation, but where connection with the local community was facilitated by meaning-changing operations that can be described as translation (or hindered by its absence). The inclusion of these points in the participants' narrative enabled a diversified analysis of the role that translation played in their Italian experience.

\section{Multilingual asylum seekers}

Asylum seeker reception centres are highly multilingual environments where residents from different backgrounds negotiate between Italian, lingua francas (English, French, Arabic), and less widely known languages. The small group of participants, originating from neighbouring countries in West Africa, contains examples of very complex and varied linguistic repertoires. Their educational 
backgrounds also differed greatly, ranging from individuals who attended school in Italy for the first time in their lives to former university students.

The participants' countries of origin are generally branded (including by participants themselves) as 'Anglophone' or 'Francophone', but their repertoires are much vaster than that, overlapping across ethnic and political fault lines. S.F., a Gambian, conducted his interview in English, but also speaks Mandinka and Wolof, as do five other interviewees from Francophone Senegal - the very existence of the two separate countries being a legacy of colonial politics. The interviewees reported speaking 27 languages in total (see Table 1). Everyone generally spoke at least one colonial language and one or more African languages: it is important to remember here, however, that the subdivision of many African languages is historically influenced by European criteria (Makoni and Pennycook 2005), and therefore the boundaries between many of the languages in question may not be clear-cut.

They speak languages such as Mandinka, Temne, Igbo: languages that their new neighbours in Umbria have generally never even heard about, and that according to the laws of the "sociolinguistics of globalisation" (Blommaert 2010) give their speakers very little linguistic advantage outside of specific African locations - especially in small Italian villages where there may be no diasporic community from their country. The refugee hospitality programme does not always arrange for individuals with the same background to share the same living quarters: very often individuals who share no native tongue live together and learn Italian together.

The interviews show how the residents of the reception centres tend to come up with strategies to manage this cohabitation of multilingual speakers. These very often revolve around a lingua franca: A.B. and B.S., two Senegalese men living in the same centre, reported that they speak Wolof between each other, but that they use Italian with residents of other nationalities. Another Senegalese, P.I., reported that, since the Nigerian residents of his centre do not speak Italian, English has become the lingua franca, often mixed with Italian. It is no wonder that some participants report moving very often from Italian to French and/or English in the space of the same conversation or even sentence - as is the case with D.A. and S.A., a Guinean and a Nigerian living in [Village I]. They frequently translanguage, drawing freely from the language resources that they have in order to compensate for gaps in their repertoires and reach mutual understanding: a key feature of multilingual environments (García and Li 2014; Pennycook and Otsuji 2015) where it interacts with translation according to contingent needs (Creese, Blackledge, and $\mathrm{Hu}$ 2018). Reception centres are multilingual environments where individuals from different linguistic, cultural and educational backgrounds are put together and try to make the most of this through communicative 
effort. Given the presence of different languages and concerns in the centres, it is no wonder that translation is a big part of an asylum seeker's everyday life, even when there is no translator present.

\section{Interlingual translation: Teachers and smartphones}

In the presence of translation professionals, asylum seekers are often the source text that needs to be made intelligible by an interpreter for local institutions. During their engagement with Italian society, however, asylum seekers develop and refine useful translation skills as they learn to manage different transfers between Italian and other languages using the resources at their disposal. This section concentrates on interlingual operations between asylum seekers and other individuals, in oral and written interactions that elude professional definitions of translation or interpreting.

Language classrooms are sites of translation, where the gaps between the linguistic and semiotic repertoires of teachers and students are filled by continuous operations of translation and where mutual understanding is sometimes laboriously achieved - not only because the language systems are different but because the experiences of the world differ (Ciribuco 2020). In the space of the same interaction, teachers may translate images in textbooks into Italian words (intersemiotically) and then may be asked to translate those words into simpler Italian sentences (intralingually), or into English (interlingually). Sometimes a student with a better command of the languages in question is called on to perform the translator's task for other students.

Teachers, social workers and other members of an asylum seeker's network may be occasionally asked to translate for them. Conversations with teachers during field work have underlined how the job of a teacher is rarely 'just' the teaching of the Italian language. Rather, it entails practical mediation between the asylum seekers and the necessities of their new life in Italy, such as helping them with their CVs, which means translating achievements and milestones that are offered in English or French by the students, into a specific variety of 'businesslike' Italian.

When they are on their own, asylum seekers translate using their phones. Smartphones are vital resources for refugees, enabling communication with distant relatives, but also facilitating information retrieval, place-making, directionfinding, linguistic operations (Kaufmann 2018), and improving their multilingual literacy (Vollmer 2018). Several participants in this research have remarked on their use of smartphones for machine translation. The increasing availability of machine translation applications has brought translation into the lives of many non-professionals who may use it for purposes such as assimilating information 
in different languages or disseminating information, as well as help language learners understand and produce foreign language texts (Yamada 2019). Asylum seekers use machine translation for these same purposes, mapping them to their predicament and their specific needs for translation.

The issue of machine translation came up in one of the first interviews. When I asked him whether he used his phone in Italian or French, D.A. replied that "there is a translator" in his phone, and that whenever he needed to write a text message in Italian, he would write it in French and the Italian equivalent would come out:

Interviewer: e... ma... tipo sul telefono quindi scrivi in francese scrivi in italiano? [so ... like ... do you write in French or Italian on your phone?]

D.A.: eh! sì cè un il mio telefono cè traduttore [eh! yes there is a translator in my phone]

\section{Interviewer: okay}

D.A.: traduttore scrivi sì io quando ho bisogno qualcosa di... [translator you write yes I when I need something in...] italiano non conosce scrivo in francese tradutto e italiano...] [Italian that I don't know I write in French translate in Italian (...)]

D.A. explicitly links machine translation with a need (bisogno) in his everyday life: that of having Italian words to use with Italian speakers. This need may arise several times in a day, and therefore cannot always be fulfilled by a language professional - hence the use of a different resource. In using the tool for dissemination, it also assumes a mimetic function, enabling D.A. to pass as a competent speaker in a text message exchange with Italian speakers, improving his self-representation.

Participants noted that machine translation helped them to learn new words in Italian: that is to say, they were using it while they were doing homework or, in D.R.'s case, doing an internship in a garage. J.Y. also uses her smartphone in conjunction with the television in her apartment, translating new words that she reads on Italian subtitles for the hard of hearing (thus adding an interlingual layer to multimodal translation). Some participants explicitly said that they used machine translation to make up for their Italian teacher's inability to translate into English or French: thus F.V. would ask her (non-English speaking) teacher the spelling of a difficult Italian word, and then go home and translate it into English on her phone. Machine translation has been found useful for beginner language learners, especially in writing tasks (Garcia and Pena 2011). Asylum seekers benefit from the use of machine translation tools as they learn Italian, but that must be mapped to their predicament and repertoire: Google Translate, the most common online translation tool, serves only a handful of African languages (thirteen 
as of March 2020), which forces most asylum seekers to rely on their proficiency in colonial languages such as English or French.

Mike Baynham and Tong King Lee, in their analysis of an exchange between a lawyer and a migrant, propose the use of Latour's Actor-Network Theory (ANT) and consider Google Translate as another node in migrants' network: "for ANT, objects are as active as humans in networks of activity, so we can see Google Translate from this perspective as occupying the space in the room and the interaction." (Baynham and Lee 2019,72) The interviews underline how this mediating agent often becomes relevant precisely when human mediators are absent or lack the necessary proficiency (as is the case with F.V.s teacher). As such, it comes to embody a specific role in their network of mediators that is either complementary or alternative to the presence of human mediators in their networks. Smartphones bring interlingual translation to their rooms in hospitality centres, giving asylum seekers the possibility of not relying on teachers and social workers, at least for the most basic translation needs.

A great deal of discussion on machine translation in the research and professional community focuses on the quality of machine translation, and whether it will ever replace human translators. However, since their use of machine translation is dictated by the need for survival, none of the participants voiced any concern about machine translation replacing human translation (to them, it actually makes up for situations where there is no professional mediator available). Only a handful of them expressed some reservations about its quality, such as A.A.:

A.A.: a me adesso... non voglio usar più google eh... traduttore... perché... ho provato a usare google traduttore un giorno... ma mi ha mandato altre cose che... ragionamente io capisco che no non è vero questa cosa... eh cerca sì leggi prima e cerca a capire... il senso di testo si c’è alcuna parole... che io non riescono a capire prima

[now I... don't want to use Google eh ... translate any more ... because... I tried using Google translate one day ... but it sent me other things that... thinking about, I realise that no this is not true... eh I try yes read and then try to understand ... the meaning of text if there's words that I cannot understand before]

A.A. had understood the gist of the source text before running it through Google Translate, and he noticed immediately that the result differed from his preliminary understanding (in the interview he says that the translation was not "true"). He showed the source text and the Google translation to a more proficient friend who confirmed his impression, suggesting that A.A. stop translating through his phone. Uncoincidentally, A.A. is one of the most educated in the group of participants, having studied at the university in Togo; his command of French and relatively good command of Italian made him realise that the machine translation 
tool - which other asylum seekers use uncritically - is far from infallible, leading him to resort to an informal mediator in his social network.

Translation has certainly "changed over the course of history in accordance with the material and technical resources at its disposal." (Littau 2016,90) Even if we consider only its interlingual aspect, translation is, and has always been, mapped on material affordances and resources. From the point of view of a sociology of translating, the advent of portable machine translation does not necessarily escape this logic - it brings forward different tools to a wider range of individuals who may not have access to other translation resources. Smartphones become material resources for translation with a different range and set of affordances to dictionaries, while the repertoire, ideologies and expectations of the translating individual are always mapped onto the tool. For some asylum seekers, machine translation may realise a basic need to be understood; more proficient (or better connected) asylum seekers may develop more complex relations with the tool, integrating it with other activities and a wide network of teachers and mediators.

While the need for interlingual translation often arises in an asylum seekers' experience, most of their narratives are occupied by other episodes where they try to bridge the cultural and linguistic distance with the village around them: operations that they may not regard as translation, but that nevertheless contain translation components. The next two sections explore two types of narratives that contain intersemiotic components of translation: street encounters and football matches.

\section{Street encounters as kinetic translation}

An asylum seeker spends most of his or her time at the hospitality centre. When they go out, interaction with the local inhabitants can be quite difficult: participants reported several episodes of casual racism in the streets. When I asked S.A. to describe [Village I], he immediately went from its smallness to the racist reactions to his presence in the streets when he first arrived:

S.A.: ... [VILLAGE] uh [VILLAGE] is a small village

Interviewer: Okay

S.A.: Is a small village the first time entered [VILLAGE] er... I don't think they don't like blacks because we are the only blacks in this... [VILLAGE] so that period they don't like us few they would see you coming from this side they would pass they would pass that other the other direction understand? so now at least... at least... I think a bit like they are now used to we... coming here 
S.A.'s story repeats itself in several interviews, with some variants - for example J.Y. and B.L., who are both mothers, lament that when they take their children to the park in [Village V], other mothers often take their children away. It is quite relevant that S.A. makes an explicit connection between [Village I]'s size, the fact that he and his fellow asylum seekers were the only black residents as far as he could see, and the fact that locals would avoid them in the street. To him it is understandable that a relatively small, tightly knit community, would react to ethnic diversity by refusing to engage.

The other side of this remark is the respondents' opinion that bigger towns in the region like Perugia had bigger African communities, and therefore were more accustomed to racial diversity than the villages where they live:

K.V.: yeah sì sì Perugia they are more used to Africa... many... many [non-] many... white! move with black... talk with black they smoke with black they drink with black... many of them but in- in [VILLAGE] eh... you can say ciao they won't... [inaudible speech] you they will just ignore you...

K.V. insisted on giving his interview in English, claiming that he does not feel confident speaking Italian since he has no Italian friends in [Village V] with whom he can practise. To him and others, bigger towns represent alternative, more diverse spaces, where other migrants have better opportunities for contact, as well as services that they could not find in villages. Several Nigerian interviewees complained that the nearest Nigerian-majority church was in Perugia, resulting in long bus trips every time that they wished to attend the service. Others mention monthly trips to African shops in Perugia to stockpile groceries that they cannot find in local supermarkets, from goat meat to okra.

Some landscapes seem to be imbued with translation; such as the building in Hong Kong recently described by Sherry Simon, where traders from all over the world convene, home to "a chorus of conversations, whose nature will change just as the wares of the building are renewed," where translation and translanguaging interweave and where "the idea of a single native tongue is replaced by the mixed public expression, adapted to specific needs." (Simon 2019, 124-25) Episodes like the one told by S.A. appear to be the opposite of this "chorus of conversations": is it possible to frame them from a translation perspective?

According to Sergey Tyulenev, one of the types of translation that plays a role in the public sphere is "kinetic translation," a type of intersemiotic translation that transfers ideas, concepts and emotions into gestures, which in turn may be translated into other gestures or words in different languages as individuals move across different contexts where gestures may be more or less transparent (Tyulenev 2018, 40). The persistence of anecdotes like the one narrated by S.A. in the asylum seekers' narratives, together with some other comments, marks the 
episode not as the opposite of translation, but as a failed kinetic translation. This is reinforced by the fact that participants make an explicit comparison between the experience of being avoided in the street and a moral teaching from their backgrounds: to greet everyone that they meet in the streets, especially if that person is their elder. This is how B.L. frames her failed interaction with Italian mothers at the park:

Interviewer: Do you talk to these mothers or...

B.L.: No because if they just ... even some you will greet them they will not answer cause ... no in Nigeria we a- we are used to greeting if we speak - when we came here in no - many things is different

Interviewer: $\mathrm{mh} \mathrm{mh}$

B.L.: is different because the way we live in Nigeria is no how they live here... I see what I learn here that if you don't know somebody you don't greet the person ... because... Nigeria if you know the person don't know the person he answer the person ... is ... elder ... elderly person

The practice of greeting people in the street even if they are strangers is most certainly not a specific Nigerian practice - there are probably several places where this is a social norm. B.L., however, considers it distinctly Nigerian because she has attempted to translate it in [Village V] and has failed. That is, she has attempted to translate a social norm that she learned in her hometown, which compels her to translate the concept of respect into gestures and words (words that she has further translated from her customary English or Urhobo into her newly-learned Italian, for example as ciao or buongiorno). Her translation is not received: the other mothers at the park, rather, ignore her. B.L., in turn, initially translated those responses as hostility; but as she got more acquainted with Italian society, she concluded that the custom there was different, and that in Italy people need at least a small degree of mutual acquaintance to greet each other.

Casual street meetings are problems of kinetic translation, as gestures and attitudes must be interpreted not only as the expressions of a feeling, but also of different cultural norms. Kinetic translation evolves as asylum seekers and older residents learn to coexist: thus B.L. learned to interpret the mothers' lack of response as a different norm of street meetings. This is a slow process of kinetic translation through which asylum seekers and locals learn to interpret each other's gestures and outward appearance and reach a form of diffident coexistence. Without the intervention of other forms of translation, however, the asylum seekers and the locals will remain confined to their own separate life-worlds, and, quite importantly, the asylum seeker would always be in the position of having to conform to local expectations. 


\section{A never-ending chain of translation: The case of football}

The interviews contain narratives of casual racism and isolation, but also of practices that helped the asylum seekers develop a sense of belonging. The interviewees took part in several social inclusion and training projects, from art classes to community gardening. From a translation point of view, these activities had several interlingual and intersemiotic aspects, between practices and words, and between Italian and other languages. In this section, for reasons of space, I will concentrate on one particularly significant activity that became an occasion for translation between asylum seekers and residents: football.

Football is a complex semiotic system: lines on the ground have a precise meaning, as do players' attire (defining who can touch the ball with their hands and who cannot) and gestures (actions may communicate an offensive or defensive attitude to the game, for example). This semiotic system is mostly the same in any part of the world where the game is practised, and in each locale it is translated into different languages, each of them having their own vocabulary to describe game-specific concepts (such as 'penalty', 'yellow card' or 'midfielder'). That is the case with the participants' home countries as well, where football is hugely popular. Many participants came to Italy with an understanding of the semiotic system of football, and a vocabulary for it in French or English. Some participants reported watching football on TV to pass the time at the reception centre or playing the game with other residents.

Four participants mention football as part of their interaction with the local landscape. At the time of the interviews, D.R. and K.A. played in semi-amateur leagues, and consider this activity to be one of the key steps towards integration. S.F. played for a team of African refugees started informally by a local teacher, which later disbanded but offered him the chance to be scouted by other teams. P.I. started an anti-racist football tournament in the town where he lives. Football is not simply a game but a vector of social inclusion for them, enabling them to be seen as something other than 'just' asylum seekers. On a translation level, we can say that their involvement with football involves a certain degree of transfer between different semiotic systems, and it also enables further translation, generating a translation space with Italian inhabitants.

When they came to Italy, the participants knew the semiotic system of football, but they had to learn how to translate it into Italian words and phrases. When I asked K.A. if he had any problem learning Italian football vocabulary, he replied that, when he started playing for his first Italian team, he had already learned a few words from television: 
Interviewer: è stato difficile all'inizio o... [was it difficult at first or...]

K.A: eh inizio... no perché perché a casa guardo sempre la partita [eh first... no because because at home I always watch the game]

Interviewer: okay ecco perché [okay that's why]

K.A.: o sì lo sento sempre quando la Juve giochi o il il Napoli giochi o così... quando fuori gioco o calcio d'angolo o... calcio di posizione... loro parlano sempre sempre [or yes I hear always when Juventus plays or Napoli plays or like... when offside or corner or ... position kick... they always always say]

Characterising translation as a semiotic problem, as Marais does, means exploring shifting relations within the Peircean triad of representamen (in this case the word "offside"), the object it relates to (a rule of football) and their interpretant (was the attacking player really beyond the defender?). When "offside" is replaced by fuorigioco or hors-jeu, translation takes the form of a representamen (word) replacing another; thus forging a new relation to object and interpretant. Translation, understood as semiosis, is not the transformation of a relatively stable source into a relatively stable target, but rather "a process that creates relationships between existing meanings, thereby creating new meanings." (Marais 2019,123) This implies that in this case the interlingual aspect of translation is only one element of a chain: a meaningful relationship has already been formed between football and a word, and now that word is put in relation with a different word. As he watched the game on television with Italian commentators, K.A. learned to match a new word, fuorigioco, to elements of a semiotic system that he knew well. It was relatively easy for him, as he already knew existing relations between football, French and Malinke - Italian was just a further passage in the chain of translation.

Meaning is therefore in continuous evolution, and can be related to other meaning in a potentially endless chain of translation. What does that entail for K.A., S.F. and the other asylum seekers who play for Umbrian teams at the lowest levels of the Italian league system? As they engage in translation, learning to match unheard words to rules and gestures that they already know, the dynamic relation between actions and words does not limit itself to the world of football; rather, it enables further translation that brings them closer to the inhabitants of the place where they live.

S.F. reported that he would often answer teammates' questions about Gambia. This sometimes originated in the fact that he would approach the team situation differently than his teammates. For example, he would refuse to sit while the coach was standing, and explained this action through a moral tenet from his home culture: "you cannot sit and the - your elder [...] is standing." As it was for the practice of greeting people in the street, leaving one's seat to an elderly 
person is hardly specific to Gambia. However, S.F. invests it with this specific meaning when his gesture translates a definition of 'respect for one's elder' that he has learned in Gambia into the world of Italian semi-amateur football - the same gesture interpreting the same concept in a different context. A surprised reaction from his teammates and the coach, who probably refuses to be considered an "elder," prompts S.F. to further translate this concept into words for their benefit, generating further occasions for translation.

K.A.'s interview contains a good example of how his presence on the pitch generated occasions for translation going beyond the language of football. When I asked K.A. what the latest Italian word that he learned was, he referred to this episode from training (Italian in italics; French in bold):

K.A.: un giorno ho detto... ho detto cosi eh in francese... ma [NAME] tu es toujours derrière ... e la loro hanno detto non hai capito non hai capito... ho detto le persone che è sempre dietro come si dice le persone... chi quando fa qualco-eh dice mister dice di fare qualcosa... lui lui non è felice lui sta stava male sempre... qualcuno ha detto lui è pigro pigro... ah! ho detto ah è questo sì tu sei pigro eh?

[one day I said so eh in French ... but (NAME) you are always behind ... and they said did not understand did not understand... I said the people who is always behind how do you say the people ... who when they do some - eh the coach says do something ... he he is not happy he feels always felt bad ... somebody said he is lazy lazy... ah! I said ah that's it yes you are lazy aren't you?]

"Tu es toujours derrière" is not the direct interlingual translation of the Italian "pigro" (lazy) - rather, it means "you are always behind." K.A. used the phrase to comment on a situation where one of his teammates would always be behind the rest of the group during the exercises. His teammates did not understand, but they still displayed their will to translate what he had said from French. The translation that resulted from this short negotiation is non-linear, and heavily context-dependent (an Italian/French dictionary will never report "Tu es toujours derrière" as a translation of "pigro") but it is rather acceptable as a humorous comment on their teammate. More importantly, this translation is their very own, creating a positive atmosphere around the football pitch.

Cronin talks about a "slow translation" ideal, pointing to the "ecological necessity of time, care and attentiveness in doing justice in translation to the nuance of local detail." $(2017,2.7)$ As K.A.'s teammates take the time to interpret his French comment, they all start a negotiation together which may be relatively slow, but ends with K.A. having learned a different word and being able to share a joke with them. This is all the more notable if we consider that K.A. lives in [Village I], the same village where S.A. reports people avoiding African asylum seekers in the streets - and where K.A. has become a well-known figure. Small 
communities may be tightly knit, but there are several activities (highly visible, and not necessarily requiring Italian proficiency) that can help the asylum seekers develop a sense of belonging and the possibility to display him/herself as more than 'just' a refugee.

Different types of activity obviously generate different examples of translation. As C.E. and A.B. learn how to make pizza as part of an internship, they must not only learn to juggle French and Italian vocabulary, but also learn how to go from speech to recipe to practise. T.L., who has made some rap music in the past, has just started studying with a local jazz teacher, meaning that he will have to translate between language(s), music sheets, and music styles. All of these occasions are fertile in that they contain the possibility for generating further translations and dialogue like K.A. and S.F.s experience as football players.

\section{Conclusion}

The asylum seekers who took part in the study may not see themselves as translators, but their existence in Italy largely depends on their ability to translate when the need arises. It is by managing transfer between different meaningmaking systems (including, but not limited to languages) that they can "[carve] out their place in pre-existing spaces." (Inghilleri 2017,108) The analysis of the interviews has shed light on what metaphors like Inghilleri's mean in practice: forging networks of informal mediators and resources, negotiating the meaning of one's physical presence, and connecting activities with multiple vocabularies. Each task requires individuals to engage with different types of meaning that is highly dependent on the nature of the task, but in the end no task is accomplished without a degree of translation. The interviews demonstrate that, as individuals interpret each other's moves and gestures and learn how to perform tasks together, translations happen, often for the fleeting moment of a street interaction. That includes activities that individuals do not generally regard as translation, but where they nevertheless negotiate the meaning of something (a gesture, a game, or another shared task) and learn to share the same landscape - or fail to do so.

This study shows that an expansion of Translation Studies to include different semiotic systems does not mean to do away with the discipline's linguistic focus, but to place interlingual translation in a wider ecology of transfer across multiple types of meaning. Also, situating translation in everyday life means acknowledging to its full potential the notion of translation as a human faculty that we use to face the unknown and learn to coexist with others in a landscape. By concentrating on small villages, this article also demonstrates that the study of translation in a space does not necessarily need superdiverse environments to support its 
claims. The village environment can function as an ecosystem of translation, constraining the types of meaning that present themselves to a newcomer (e.g. lacking a place of worship) but also offering specific pathways towards dialogue (as in K.A.'s case, where membership of a local football team made him a well-known figure).

This article is based on the in-depth analysis of a relatively small sample of qualitative data from a specific context. The narratives under examination, however, contain several clues as what can be accomplished by research focusing on the "lived experience of translation." Research based on individuals and their relation to the landscape opens up the possibility of understanding ecosystems of translation in a more complex sense by incorporating different semiotic systems. Future research may expand the methodology, with an increasing use of ethnographic techniques, possibly inspired by applied linguistics and its very recent engagement with translation (Creese, Blackledge and $\mathrm{Hu}$ 2018; Baynham and Lee 2019) that will capture these fleeting translation moments as they happen. By putting individuals' translation skills at the centre of integration research, it will be possible to inform a view of integration that is based on individuals negotiating and compromising between different worldviews.

\section{Funding}

IRISH RESEARCH COUNCIL An Chomhairle um Thaighde in Éirinn

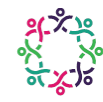

\section{CAROLINE}

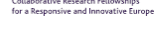

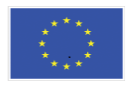

This project has received funding from the Irish Research Council and from the European Union's Horizon 2020 research and innovation programme under the Marie SkłodowskaCurie grant agreement No. 713279. This publication reflects only the author's views, and the IRC or the REA are not responsible for any use that may be made of the information it contains.

\section{Acknowledgements}

I would like to express my gratitude to Tamat's staff for being with me in the field and teaching me about development and social inclusion. I would also like to thank all the associations and NGOs in Umbria who helped me recruit participants.

Thanks to the two reviewers and the editors at Translation Spaces for their helpful and insightful comments. 


\section{References}

Baker, Mona. 2019. Translation and Conflict. A Narrative Account. 2nd ed. London: Routledge. Baynham, Mike, and Tong King Lee. 2019. Translation and Translanguaging. Oxford:

Routledge. https://doi.org/10.4324/9781315158877

Blommaert, Jan. 2010. The Sociolinguistics of Globalization. Cambridge: Cambridge University Press. https://doi.org/10.1017/CBO9780511845307

Busch, Brigitta. 2017. "Expanding the Notion of the Linguistic Repertoire: On the Concept of Spracherleben - The Lived Experience of Language." Applied Linguistics 38 (3): 340-58.

Ciribuco, Andrea. 2020. "How Do You Say Kélén-Kélén in Italian? Migration, Landscape and Untranslatable Food.” Translation Studies 13 (1): 99-115.

https://doi.org/10.1080/14781700.2019.1662837

Creese, Angela, Adrian Blackledge, and Rachel Hu. 2018. "Translanguaging and Translation: The Construction of Social Difference across City Spaces." International Journal of Bilingual Education and Bilingualism 21 (7): 841-52. https://doi.org/10.1080/13670050.2017.1323445

Cronin, Michael. 2017. Eco-Translation. Translation and Ecology in the Age of Anthropocene. Oxford: Routledge. Kindle Edition. https://doi.org/10.4324/9781315689357

García, Ofelia, and Wei Li. 2014. Translanguaging. Language, Bilingualism and Education. Basingstoke: Palgrave Macmillan.

Garcia, Ignacio, and María Isabel Pena. 2011. "Machine Translation-Assisted Language Learning: Writing for Beginners." Computer Assisted Language Learning 24 (5): 471-87. https://doi.org/10.1080/09588221.2011.582687

Inghilleri, Moira. 2005. "Mediating Zones of Uncertainty: Interpreter Agency, the Interpreting Habitus and Political Asylum Adjudication.” The Translator 11 (1): 69-85. https://doi.org/10.1080/13556509.2005.10799190

Inghilleri, Moira. 2017. Translation and Migration. New York: Routledge.

Jakobson, Roman. 1959. “On Linguistic Aspects of Translation.” In On Translation, edited by R.A. Brower, 232-39. Cambridge, MA: Harvard University Press.

Jiménez-Ivars, Amparo, and Ruth León-Pinilla. 2018. "Interpreting in Refugee Contexts. A Descriptive and Qualitative Study." Language and Communication 60: 28-43. https://doi.org/10.1016/j.langcom.2018.01.009

Kaufmann, Katja. 2018. "Navigating a New Life: Syrian Refugees and Their Smartphones in Vienna." Information Communication and Society 21 (6): 882-98. https://doi.org/10.1080/1369118X.2018.1437205

Killman, Jeffrey. 2020. "Interpreting for Asylum Seekers and Their Attorneys: The Challenge of Agency.” Perspectives 28 (1): 1-17. https://doi.org/10.1080/0907676X.2019.1615518

Littau, Karin. 2016. "Translation and the Materialities of Communication." Translation Studies 9 (1): 82-96. https://doi.org/10.1080/14781700.2015.1063449

Makoni, Sinfree, and Alastair Pennycook. 2005. "Disinventing and (Re) Constituting Languages." Critical Inquiry in Language Studies 2 (3): 137-56. https://doi.org/10.1207/s15427595cils0203_1

Marais, Kobus. 2014. Translation Theory and Development Studies. A Complexity Theory Approach. New York: Routledge. https://doi.org/10.4324/9780203768280

Marais, Kobus. 2019. A (Bio) Semiotic Theory of Translation. New York: Routledge.

Ministero dell'Interno. 2018. Rapporto Annuale SPRAR/SIPROIMI 2018. 
Nekvapil, Jirí. 2003. "Language Biographies and the Analysis of Language Situations: On the Life of the German Community in the Czech Republic." International Journal of the Sociology of Language, 162: 63-83.

Pennycook, Alastair, and Emi Otsuji. 2015. Metrolingualism. Language in the City. Oxford: Routledge. https://doi.org/10.4324/9781315724225

Pratt, Mary Louise. 1991. "Arts of the Contact Zone." Profession: 33-40.

Simon, Sherry. 2012. Cities in Translation. Intersections of Language and Memory. New York: Routledge.

Simon, Sherry. 2019. Translation Sites. A Field Guide. Oxford: Routledge. https://doi.org/10.4324/9781315311098

Stevenson, Patrick. 2017. Language and Migration in a Multilingual Metropolis: Berlin Lives. Cham: Palgrave Macmillan. https://doi.org/10.1007/978-3-319-40606-o

Tyulenev, Sergey. 2018. Translation in the Public Sphere. Cham: Palgrave Macmillan. https://doi.org/10.1007/978-3-319-78358-1

Vertovec, Steven. 2007. "Super-Diversity and Its Implications." Ethnic and Racial Studies 30 (6): 1024-54. https://doi.org/10.1080/01419870701599465

Villa, Matteo, Valeria Emmi, and Elena Corradi. 2018. "Migranti: La sfida dell'integrazione." Milano: ISPI/CESVI.

Vollmer, Stefan. 2018. "Syrian Newcomers and their Digital Literacy Practices." Language Issues 28 (2): 66-72.

Wolf, Michaela. 2011. "Mapping the Field: Sociological Perspectives on Translation." International Journal of the Sociology of Language 207: 1-28. https://doi.org/10.1515/ijsl.2011.001

Yamada, Masaru. 2019. "Language Learners and Non-Professional Translators as Users." In The Routledge Handbook of Translation and Technology, edited by Minako O'Hagan. Abingdon: Routledge. https://doi.org/10.4324/9781315311258-11

\section{Address for correspondence}

\section{Andrea Ciribuco}

National University of Ireland Galway

Moore Institute Room 2010

Hardiman Research Building

University Road

$\mathrm{H}_{91} \mathrm{TK}_{33}$ Galway

Ireland

andrea.ciribuco@nuigalway.ie

https://orcid.org/oooo-0002-5709-6061 


\section{Publication history}

Date received: 3 April 2020

Date accepted: 10 September 2020

Published online: 27 October 2020 